Filip CIEPŁY*

\title{
UWAGI W PRZEDMIOCIE PARADYGMATU NAUK PRAWNYCH
}

\section{Wprowadzenie}

W naukach prawnych, zwłaszcza w teorii prawa i jego poszczególnych dogmatykach, podstawowe założenia określające paradygmat badawczy wydają się być konglomeratem trzech zasadniczych, w dużej mierze konkurujących ze sobą, nurtów myśli filozoficzno-prawnej: logiki i etyki klasycznej, odwołujących się do wartości prawdy i sprawiedliwości, oświeceniowego racjonalizmu i utylitaryzmu oraz aksjomatów pozytywistycznych ${ }^{1}$. O ile logika klasyczna wciąż zajmuje istotne miejsce zarówno w edukacji prawniczej, jak i analizach naukowych, o tyle już na przykład klasyczna aksjologia odwołująca się do racjonalizacji sprawiedliwościowej, chociaż wciąż obecna, to począwszy od epoki oświecenia, a w szczególności pod naporem idei pozytywistycznych, w poszczególnych dogmatykach zajmuje raczej symboliczną pozycję zarówno w edukacji, jak i praktyce tworzenia i stosowania prawa ${ }^{2}$. Na przykład w nauce prawa karnego materialnego tak ważny dla aksjologii prawa problem jak zagadnienie sprawiedliwości bywa odnotowywany $\mathrm{w}$ podręcznikach akademickich, chociażby w zakresie enumeracji funkcji

* Doktor nauk prawnych, adiunkt w Instytucie Prawa i Ekonomii WZPiNoS KUL w Stalowej Woli.

${ }^{1}$ Jako paradygmat pojmuję za T. S. Kuhnem zespół instrumentalnych, teoretycznych i metafizycznych (filozoficznych) przekonań podzielanych przez grupę uczonych. Zob. T. S. Kuhn, Dwa bieguny. Tradycja i nowatorstwo w badaniach naukowych, Warszawa 1985, s. 407.

2 Istotnym wyjątkiem są prace z zakresu ogólnej teorii prawa, w których autorzy aksjologię czynią podstawą swoich rozważań. Są to opracowania m.in. Z. Ziembińskiego, J. Wróblewskiego, W. Langa, K. Opałka, M. Boreckiej-Arctowej, M. Ossowskiej, Cz. Znamierowskiego, M. Zirk-Sadowskiego, K. Pałeckiego, L. Leszczyńskiego, M. Korneli, S. Wojtczak. Por. A. Grabowska, Metodologiczne zagadnienia prawoznawstwa. Teoria prawa Kazimierza Opałka i Jerzego Wróblewskiego we wspótczesnym prawoznawstwie, [w:] T. Bekrycht, M. Zirk-Sadowski (red.), Wpływ teorii Jerzego Wróblewskiego na współczesne prawoznawstwo, Warszawa 2011, s. 21-22; P. Dutkiewicz, Problem aksjologicznych podstaw prawa we wspótczesnej polskiej filozofii i teorii prawa, Kraków 1996, s. 5-17. 
prawa karnego, niemniej jednak, wbrew treści Konstytucji RP z 1997 r., sprawiedliwość, jako wartość i zasada prawa polskiego, czy też prawnie relewantne uniwersalne wartości prawdy, dobra i piękna nie stanowią wśród badaczy ważkiego kryterium w dokonywaniu szczegółowych analiz dogmatycznych ${ }^{3}$. Przedstawiciele dogmatyki prawa zasadniczo niechętnie odczytują z treści aktów normatywnych zakodowane w nich niekiedy przez prawodawcę rozstrzygnięcia sporów teoretycznych czy światopoglądowych mających znaczenie paradygmatyczne ${ }^{4}$.

$\mathrm{W}$ minionych dekadach $\mathrm{w}$ naukach prawnych racjonalizm oświecenia oraz pozytywistycznie i materialistycznie nastawiony modernizm stawiał na demaskację tzw. założeń mitycznych i metafizycznych w interpretacji prawa, co na gruncie nauk penalnych wyrażało się zasadniczym odrzuceniem argumentacji aksjologicznej i ukierunkowaniem tworzenia i wykładni przepisów prawnych na kształtowanie procesów społecznych postrzeganych jako zjawiska mierzalne metodami techniczno-ilościowymi, zdeterminowane i przewidywalne ${ }^{5}$. Utrwaliło się przekonanie, że celem kreowania i stosowania norm prawnych powinno być dążenie do jak najdalej idącej ich racjonalizacji, rozumianej jednak $\mathrm{w}$ perspektywie postulatów scjentyzmu i naturalizmu metodologicznego. Spuścizną tego podejścia jest dość rozpowszechnione $\mathrm{w}$ doktrynie prawa karnego promowanie ideału prawa racjonalnego, postrzeganego wąsko jako rodzaj instrumentu planowego kształtowania stosunków społecznych. Prawo karne w znacznej mierze bywa redukowane do poziomu techniki celowego sterowania procesami zachodzącymi w społeczeństwie i oceniane według kryteriów skuteczności w zakresie społecznej kontroli ${ }^{6}$.

${ }^{3}$ Odmienne podejście jest zauważalne w nauce procesu karnego. Zob. J. Skorupka, O sprawiedliwości procesu karnego, Warszawa 2013.

${ }^{4}$ Zob. F. Ciepły, Konstytucyjne podstawy rozstrzygania sporów odnoszacych się do człowieka jako sprawcy czynu karnoprawnie relewantnego, „Czasopismo Prawa Karnego i Nauk Penalnych” - artykuł przyjęty do druku w marcu 2017 r. Por. A. Łabno, Sprawiedliwość jako najwyższa wartość porzaddku prawnego. Rozważania na tle art. 1 ust. 1 Konstytucji Hiszpanii z 1978 r., [w:] I. Bogucka, Z. Tobor (red.), Prawo a wartości. Księga jubileuszowa Profesora Józefa Nowackiego, Kraków 2003, s. 178.

${ }^{5}$ Zob. A. Sulikowski, Współczesny paradygmat sadownictwa konstytucyjnego wobec kryzysu nowoczesności, Wrocław 2008, s. 99-100; J. Warylewski, [w:] A. Marek (red.), System prawa karnego, t. I, Zagadnienia ogólne, Warszawa 2010, s. 58.

${ }^{6}$ Por. J. Utrat-Milecki, Prawo karne i polityka kryminalna jako podsystem kontroli społecznej. Analiza integralnokulturowa, [w:] M. Filar, J. Utrat-Milecki (red.), Kulturowe uwarunkowania polityki kryminalnej, Warszawa 2014, s. 55; T. Kaczmarek, Patologia społeczna a polityka kryminalna, „Palestra" 1987, nr 6, s. 30; K. Krajewski, [w:] A. Marek (red.), System prawa karnego, t. I, Zagadnienia ogólne, Warszawa 2010, s. 100; M. Peno, Nowoczesna polityka kryminalna w świetle koncepcji polityki tworzenia prawa Jerzego Wróblewskiego, [w:] T. Bekrycht, M. Zirk-Sadowski (red.), Wptyw teorii Jerzego Wróblewskiego na współczesne prawoznawstwo, Warszawa 2011, s. 67-68. 


\section{Postmodernistyczna kontestacja nauki prawa}

Dająca się czasem zauważyć na gruncie poszczególnych dyscyplin prawniczych pewna niechęć do podejmowania analiz aksjologicznych wynika nie tylko z charakterystycznego dla pozytywizmu prawnego nominalnego odcięcia się od pozaprawnych ocen moralnych systemu prawnego, ale ponadto katalizuje się w aktualnym kontekście kulturowym, w którym operują współcześni twórcy i interpretatorzy prawa. Jak się wskazuje, cechą charakterystyczną współczesnej, być może już kończącej się, epoki zwanej postmodernizmem jest chęć odrzucenia w dyskursie dotyczącym problemów społecznych wszelkich obiektywnych założeń. W postmodernistycznej filozofii i metodologii nauk kontestuje się zarówno klasyczne, jak i oświeceniowe oraz pozytywistyczne aksjomaty. W postmodernistycznej „narracji” neguje się istnienie jakichkolwiek uniwersalnych i neutralnych kryteriów debaty społecznej i kulturowej. Podważa się możliwość formułowania stanowczych twierdzeń także w dziedzinach stanowiących ważne przedpole dla analiz prawniczych, na przykład w ramach takich dyscyplin naukowych jak ontologia, antropologia, teoria poznania, etyka, psychologia, socjologia, ekonomia czy politologia. Relatywizacja dotychczas uznanych za stałe punktów odniesienia prowadzi do traktowania zróżnicowanych założeń i odmiennych poglądów jedynie jako równoprawnych opcji, opinii, narracji, gier językowych. Pojawiły się nawet pesymistyczne głosy, że teoretyczne podstawy uprawiania nauki prawa w niektórych jego gałęziach znajdują się na tym samym poziomie wiedzy co mitologia. Wiele sił i środków wydaje się na realizację celów założonych przez organy legislacyjne, ale baza w ten sposób stworzona nierzadko bywa czymś innym niż chwiejną wiarą ${ }^{7}$.

Kryzys myślenia modernistycznego w doktrynach politycznych i prawoznawstwie, a wraz nim krytyka oświeceniowych i pozytywistycznych projektów reform społecznych oraz modernistycznie rozumianej racjonalizacji prawa, rozpoczęły się w państwach zachodnich już w latach 60. XX w. Od tego czasu kontestatorzy modernizmu negatywnie odnoszą się do projektów filozofów oświecenia, którzy powołując się na rzekomo uniwersalne prawa nauki i rozumu, wzywali do zbudowania na nich nowego porządku społecznego. Postmoderniści odrzucają także założenia pozytywistyczne, takie jak determinizm, scjentyzm, naturalizm, instrumentalnie zorientowany racjonalizm. Krytykując modernistyczny model nauki, idą znacznie dalej niż poprzedzający ich przedstawiciele tzw. nurtu antynaturalistycznego. Odrzucają nie tylko założenie, że nauki społeczne powinny naśladować metody stosowane

7 Zob. L. Lernell, Wspótczesne zagadnienia polityki kryminalnej. Problemy kryminologiczne i penologiczne, Warszawa 1978, s. 8-9. 
w przyrodoznawstwie, ale za mit uznają twierdzenie, że zasady uprawiania nauki dają się ująć $\mathrm{w}$ jakikolwiek system z góry ustalonych reguł i kryteriów, które mogłyby określić metody badania faktów i kryteria naukowości twierdzeń. W tym ujęciu rola nauk społecznych dla prawoznawstwa ma być zdecydowanie skromniejsza od tej, którą przypisywano im w przeszłości ${ }^{8}$.

Według przedstawicieli postmodernizmu nauki społeczne i nawiązujące do nich prawoznawstwo nie powinny aspirować do roli narzędzia inżynierii społecznej. Piętnuje się przy tym postawę naukowców pretendujących do roli „legislatorów” autorytatywnie dyktujących organom prawodawczym tak zwane prawa rozumu. Modernistycznej nauce prawa zarzuca się scjentystyczną ortodoksję, która ugrzęzła w skostniałym świecie anachronicznych naturalistycznych pojęć, konstrukcji i metodologii. Zarówno ta oparta na logice klasycznej, jak i modernistyczna postawa badawcza ma być odpowiedzialna za konserwatyzm prawniczych elit i ich niezdolność do rozwiązywania problemów świata współczesnego, a w szczególności nie jest zdolna do adekwatnej odpowiedzi na specyficzne problemy społeczności lokalnych czy grup mniejszościowych. W narracji postmodernistycznej państwo i prawo są przedstawiane jako zbyt niebezpiecznie zbiurokratyzowane i sformalizowane'. Praktyka rozwiązywania kwestii politycznych in abstracto, suponująca tak zwaną emancypację reguły, przedstawiana jest jako nieuzasadniona przemoc wobec słabszych i lokalnych struktur ${ }^{10}$.

Postmodernistyczna krytyka klasycznych, oświeceniowych i pozytywistycznych zobiektywizowanych metod rozstrzygania problemów etycznych, społecznych i prawnych, dominacja założeń subiektywistycznych i relatywistycznych sprawiają, że współcześnie coraz trudniej prowadzi się jakiekolwiek badania normatywne. Relatywizacja i subiektywizacja wartości, a więc odrzucenie obiektywizmu i kognitywizmu moralnego, przekładają się na akcentowanie wieloznaczności podstawowych dla analiz aksjologicznych pojęć, co dekonstruuje argumentację interpretacyjną także na niwie analiz prawniczych. Skoro jakiekolwiek założenia i pojęcia aksjologiczne mają stanowić jedynie kwestię ukształtowanych w ten czy inny sposób emocji lub preferencji, to $\mathrm{w}$ konsekwencji nie istnieje żaden uprzywilejowany, a tym bardziej obiektywny zasadniczy punkt odniesienia, z perspektywy którego możliwa byłaby istotna krytyka i odrzucenie albo przyjęcie określonych powinnościowych sformułowań ${ }^{11}$.

${ }^{8}$ Por. L. Morawski, Główne problemy współczesnej filozofii prawa. Prawo w toku przemian, Warszawa 2003, s. 49-58.

9 Tamże.

10 Por. A. Sulikowski, O możliwościach postmodernizacji nauki prawa konstytucyjnego, „Państwo i Prawo" 2010, nr 12, s. 8-9.

11 Por. T. Pietrzykowski, Wyzwania moralne. Etyczne problemy prawa, Warszawa 2010, s. 32-33. 
Każdy, kto zajmuje się sferą normatywną i na gruncie metody hermeneutycznej zamierza formułować normy postępowania, napotyka zastrzeżenie, że nie ma leżących u podstaw tych reguł obiektywnych wartości ${ }^{12}$. Podnosi się, że aksjologia prawa jest zależna od przyjętej ontologii prawa, a w jej przedmiocie nie ma poglądów akceptowanych przez wszystkich ${ }^{13}$. Narracja postmodernistyczna odrzuca regulatywną, stabilizującą i racjonalizującą rolę prawa opartego na spójnym systemie wartości. W to miejsce proponuje „mglistą niepewność” i „nieprzejrzystość aksjologiczną”"14. Zabsolutyzowana teza o wielości równoważnych poglądów etycznych implikuje relatywizm moralny, a na płaszczyźnie systemowej nihilizm aksjologiczny, co oznacza poważne problemy w zakresie spójnego tworzenia, interpretowania i stosowania prawa. W działalności prawotwórczej i interpretacyjnej faktycznie nie da się jednak podejmować istotnych rozstrzygnięć bez uwzględniania zasadniczych wyborów aksjologicznych, koniecznych dla skonstruowania spójnego systemu normatywnego ${ }^{15}$.

Warto zauważyć, że chociaż teoretycy postmodernistyczni podkreślają płynność wszystkiego, to jednak paradoksalnie są bardzo stanowczy w tym, co sami twierdzą, wikłając się tym samym w problem samozaprzeczenia ${ }^{16}$. Negując jakiekolwiek obiektywne założenia, de facto narzucają innym własny relatywistyczny, subiektywistyczny punkt widzenia jako powszechnie obowiązujący. Obalając wiarę w racjonalną dyskusję, przedstawiają określone racje, by wykazać słuszność własnych spostrzeżeń. Mająca wyzwalać od tzw. wielkich metanarracji postmodernistyczna ideologia „anty” jest coraz powszechniej prezentowana jako obowiązująca ideologia, sama stając się „wielką metanarracją" wykluczającą myślących inaczej" ${ }^{17}$. Myślowe prądy postmodernizmu, głosząc uwolnienie prawa od "rozumu uniwersalnego", "kreowania znaczeń", „terroru prawdy”, „totalitaryzmu sprawiedliwości”, narzucają własną antyaksjologię, przymuszając presją kulturową, opinią wpływowych ośrodków naukowych, a niekiedy wprost regulacjami prawnymi do negacji klasycznego pojmowania podstawowych pojęć etycznych i prawnych ${ }^{18}$. Wyzwalanie od rzekomej opresji logocentryzmu ma tendencję

${ }^{12}$ H. Arkes, First things: an inquiry into the first principles of morals and justice, Princeton 1986, s. 51.

13 P. Dutkiewicz, Problem aksjologicznych..., s. 5-17.

14 Zob. J. Oniszczuk, Filozofia i teoria prawa, Warszawa 2012, s. 874.

15 P. Winczorek, Konstytucja i wartości, [w:] J. Trzciński (red.), Charakter i struktura norm konstytucji, Warszawa 1997, s. 35.

${ }^{16}$ B. Wojciechowski, Dekonstrukcja. Między prawem i sprawiedliwościa, [w:] L. Leszczyński (red.), Zmiany społeczne a zmiany w prawie, Lublin 1998, s. 314-315.

17 Por. H. Arkes, First things..., s. 51.

18 Zob. J. Oniszczuk, Zainteresowania racjonalnościa. Przykłady starszych podejść do racjonalności (kilka uwag), [w:] R.M. Czarny, K. Spryszak (red.), Państwo i prawo wobec wspótczesnych wyzwań. Teoria i filozofia państwa i prawa oraz aksjologia demokracji i ochrony praw człowieka. Ksiega 
do transformowania $\mathrm{w}$ niektórych dziedzinach $\mathrm{w}$ realnie opresywną dyktaturę relatywizmu.

\section{Immanentny logocentryzm systemu prawnego}

Charakterystyczna dla postmodernistycznego sposobu myślenia relatywizacja uznanych za stałe punktów odniesienia, dekonstrukcja znaczeń, tworzenie humbugów pojęciowych sprawiają, że próby przenoszenia narracji postmodernistycznej na grunt nauk prawnych zasadniczo muszą kończyć się niepowodzeniem. W systemie prawa, w szczególności prawa kontynentalnego, wykładnia prawa, jako rekonstrukcja norm prawnych z przepisów prawnych, opiera się na założeniu, że stosowane przez prawodawcę pojęcia języka prawnego, jako „nośniki” zawartych w nich zobiektywizowanych i powszechnie wiążących znaczeń, mają swój zakodowany i określony zakres treściowy. Treść normy prawnej wymaga ustalenia, a więc odczytania, a nie wykreowania. Prawo z właściwymi mu metodami jego tworzenia i interpretacji - przeciwnie niż postmodernistyczny dekonstrukcjonizm - charakteryzuje w związku z tym dążenie do klaryfikacji pojęć, konstruowania definicji, precyzyjnego określenia desygnatu. Zasady prawidłowej legislacji i uznane w prawoznawstwie metody wykładni wymagają najdalej posuniętej jednoznaczności oraz merytorycznego ukierunkowania na realizację określonych wartości stanowiących zobiektywizowane aksjologiczne podstawy systemu prawnego. Dzięki konserwatyzmowi na płaszczyznach semantyki i aksjologii prawo zapewnia sobie nie tylko stabilność i ciągłość systemową, ale możliwość w ogóle jego klarownej i spójnej interpretacji. Narracja postmodernistyczna przeciwnie, z założenia obala zastane paradygmaty, dekonstruuje system, ucieka od reguły, stąd integracja prawoznawstwa z naukami humanistycznymi, przesiąkniętymi ideą dekonstrukcji, jest niezwykle trudna, jeśli nie niemożliwa ${ }^{19}$.

W szczególności sprzeczne z istotą wykładni prawa są próby jego interpretacji w duchu politycznie zaprojektowanej transgresji kontrkulturowej ${ }^{20}$. Zmiany w kulturze, nawet te radykalne, mogą być promowane na płaszczyźnie prawnej, ale wyłącznie przez zmianę przepisów prawa (co w kontekście demokratycznego państwa prawnego wymaga określonego konsensusu

\footnotetext{
jubileuszowa Profesora Jerzego Jaskierni, Toruń 2012, s. 121; A. Kozak, Myślenie analityczne w nauce prawa i praktyce prawniczej, Wrocław 2010, s. 225-226.

19 Por. K. Wojtyczek, Polska nauka prawa konstytucyjnego na przełomie wieków, [w:] M. Zubik (red.), Dwadzieścia lat transformacji ustrojowej w Polsce, Warszawa 2010, s. 42-43.

20 Szerzej zob. F. Ciepły, Preferencje aksjologiczne ustrojodawcy a prawne granice wolności sztuki, „Zeszyty Artystyczne” 2015, t. 26, s. 31-40.
} 
społecznego), a nie przez dekonstrukcję desygnatów pojęć aksjologicznych i normatywnych w ramach procesu wykładniczego. System prawny ewoluuje razem z kulturą, ale dzięki nowelizacji prawa, a nie dekonstrukcji znaczeń pojęć języka prawnego. Organ stosujący prawo nie może w procesie wykładni opierać się na swobodnej, indywidualistycznej, arbitralnej interpretacji pojęć, nieskrępowanej „wielkimi metanarracjami”, bo tym samym organ ten faktycznie tworzyłby normę prawną, a nie dekodował ją z przepisu. Byłoby to sprzeczne z zasadami podziału władzy, praworządności, demokratycznego państwa prawnego. Organ w szczególności powinien brać pod uwagę założenia, preferencje aksjologiczne, „metanarracje”, na których oparł się prawodawca. Akt prawny ze swojej istoty stanowi barierę dla arbitralności organu stosującego prawo, a nie zaproszenie dla mniej lub bardziej dowolnej aktywności interpretacyjnej dekonstruującej zastane w prawie pojęcia. Wykraczający poza powszechnie uznane normy kulturowe aktywizm sędziowski oznacza, że organ stosujący prawo ze sługi ustawy przekształca się w jej pana, a więc uzurpuje sobie rolę prawodawcy ${ }^{21}$. Subiektywistyczna ewolucja rozumienia tekstu prawnego po przekroczeniu pewnego progu jakościowego przekształca się w rzeczywisty bunt przeciwko prawu, ukrytą postać obalenia prawa, odrzucenia uznanego przez prawodawcę jego oryginalnego i zamierzonego znaczenia ${ }^{22}$. Interpretator aktu normatywnego, dokonując wyboru paradygmatu i wskazując na podstawy aksjologiczne prowadzonej wykładni, nie powinien odwoływać się w tym zakresie przede wszystkim do własnych ocen ani do zmiennych i uzależnionych od bieżącej mody trendów ideologicznych, ale do fundamentalnych wartości zakodowanych w języku prawa, przede wszystkim uwzględniając wartości wyrażone w preambule oraz treści normatywnej ustawy zasadniczej ${ }^{23}$.

\section{Podsumowanie}

O ile chęć zrealizowania najbardziej nośnych postulatów postmodernizmu na gruncie nauk prawnych oznaczałaby wejście w pułapkę metodologicznego impasu, o tyle pewne intuicje tego kierunku myślowego mogą stać

${ }^{21}$ Por. K. Wojtyczek, Polska nauka..., s. 43.

${ }^{22}$ L. Garlicki, Aksjologiczne podstawy reinterpretacji konstytucji, [w:] M. Zubik (red.), Dwadzieścia lat transformacji ustrojowej w Polsce, Warszawa 2010, s. 87. Por. R. Sarkowicz, Poziomowa interpretacja tekstu prawnego, Kraków 1995.

${ }_{23}$ Por. J. Mikołajewicz, O zasadzie równej miary w wyznaczaniu sytuacji prawnych, [w:] A. Dębiński, P. Stanisz, T. Barankiewicz, J. Potrzeszcz, W. Sz. Staszewski, A. Szarek-Zwijacz, M. Wójcik (red.), Abiit, non obiit. Księga poświęcona pamięci Księdza Profesora Antoniego Kościa SVD, Lublin 2013, s. 221. 
się inspiracją dla dalszych badań nad paradygmatycznymi problemami tworzenia i interpretacji prawa, podkreślając znaczenie analiz aksjologicznych ${ }^{24}$. Po pierwsze, postmodernizm trafnie kontestuje i falsyfikuje jako fundament metodologiczny nauk prawnych wysterylizowany z podstawowych wartości społecznych uniwersalizujący racjonalizm oświecenia oraz pozytywistyczny naturalizm. Ponadto postmodernizm zwraca uwagę, że język, w tym język prawny, i funkcjonujące w nim pojęcia są nosicielami określonych kontekstów ich interpretacji. To właśnie ten kontekst pozwala lepiej zrozumieć założenia systemowe, $\mathrm{w}$ których język prawny i wyrażone w nim instytucje powstały, i w świetle których należy je rozumieć. Za użytymi przez prawodawcę pojęciami stoi zawsze jakaś „metanarracja”, którą trzeba zidentyfikować i uwzględniać przy dekodowaniu treści norm prawnych. Za każdym językiem stoi określony sposób myślenia, wizja człowieka, określony system moralny, dana kultura, do której fundamentalnych założeń trzeba dotrzeć, aby poznać aksjologię systemu prawa, a co za tym idzie, aby lepiej zrozumieć treść poszczególnych norm prawnych.

Postmodernistyczna krytyka paradygmatu nauk prawnych uprzytamnia, że system prawny zakodowany w określonym języku jest znaczeniowo, aksjologicznie i normatywnie zakotwiczony w określonej cywilizacji i właściwym jej systemie wartości. W procesie wykładni prawa należy zwrócić szczególną uwagę na kryjący się za określonym językiem kontekst antropologiczny, etyczny, kulturowy, stanowiący pierwotne, relewantne dla treści norm tło aksjologicznych i normatywnych rozstrzygnięć prawodawcy. Postmodernizm, który według ocen niektórych obserwatorów coraz bardziej traci na znaczeniu - paradoksalnie, a rebour - uświadamia konieczność budowania i rekonstruowania (a nie dekonstruowania) systemu prawnego na podstawie określonego, oryginalnego, realnie stojącego za wyborem prawodawcy systemu wartości.

Wewnętrznej racjonalności i aksjologii systemu prawnego nie da się zanegować, należą one do jego istoty. Racjonalność tego systemu nie powinna być jednak traktowana jako racjonalność instrumentalna, wdrażająca obce temu systemowi ideologiczne programy inżynierii społecznej, ale jako racjonalność oparta na wpisanych w ten system, uznanych przez prawodawcę, kulturowo interpretowanych fundamentach aksjologicznych, które domagają się identyfikacji i uwzględnienia w naukowej analizie i interpretacji prawa.

Słowa kluczowe: wykładnia prawa, aksjologia prawa, filozofia prawa, paradygmat nauk prawnych, postmodernizm.

${ }^{24}$ Por. M. Peno, Postmodernizacja nauki prawa karnego - geneza i efekty, [w:] A. Samonek (red.), Teoria prawa. Między nowoczesnościa a ponowoczesnościa, Kraków 2012, s. 272. 


\section{Bibliografia}

Arkes H., First things: an inquiry into the first principles of morals and justice, Princeton 1986.

Ciepły F., Konstytucyjne podstawy rozstrzygania sporów odnoszacych się do człowieka jako sprawcy czynu karnoprawnie relewantnego, "Czasopismo Prawa Karnego i Nauk Penalnych" - artykuł przyjęty do druku w marcu 2017 r.

Ciepły F., Preferencje aksjologiczne ustrojodawcy a prawne granice wolności sztuki, „Zeszyty Artystyczne" 2015, t. 26.

Dutkiewicz P., Problem aksjologicznych podstaw prawa we wspótczesnej polskiej filozofii i teorii prawa, Kraków 1996.

Garlicki L., Aksjologiczne podstawy reinterpretacji konstytucji, [w:] M. Zubik (red.), Dwadzieścia lat transformacji ustrojowej w Polsce, Warszawa 2010.

Grabowska A., Metodologiczne zagadnienia prawoznawstwa. Teoria prawa Kazimierza Opałka i Jerzego Wróblewskiego we wspótczesnym prawoznawstwie, [w:] T. Bekrycht, M. Zirk-Sadowski (red.), Wpływ teorii Jerzego Wróblewskiego na współczesne prawoznawstwo, Warszawa 2011.

Kaczmarek T., Patologia społeczna a polityka kryminalna, „Palestra” 1987, nr 6.

Kozak A., Myślenie analityczne w nauce prawa i praktyce prawniczej, Wrocław 2010.

Krajewski K., [w:] A. Marek (red.), System prawa karnego, t. I, Zagadnienia ogólne, Warszawa 2010.

Kuhn T. S., Dwa bieguny. Tradycja i nowatorstwo w badaniach naukowych, Warszawa 1985.

Mikołajewicz J., O zasadzie równej miary w wyznaczaniu sytuacji prawnych, [w:] A. Dębiński, P. Stanisz, T. Barankiewicz, J. Potrzeszcz, W. Sz. Staszewski, A. Szarek-Zwijacz, M. Wójcik (red.), Abiit, non obiit. Księga poświęcona pamięci Księdza Profesora Antoniego Kościa SVD, Lublin 2013.

Lernell L., Wspótczesne zagadnienia polityki kryminalnej. Problemy kryminologiczne i penologiczne, Warszawa 1978.

Łabno A., Sprawiedliwość jako najwyższa wartość porządku prawnego. Rozważania na tle art. 1 ust. 1 Konstytucji Hiszpanii z 1978 r., [w:] I. Bogucka, Z. Tobor (red.), Prawo a wartości. Ksiega jubileuszowa Profesora Józefa Nowackiego, Kraków 2003.

Morawski L., Główne problemy wspótczesnej filozofii prawa. Prawo w toku przemian, Warszawa 2003.

Oniszczuk J., Filozofia i teoria prawa, Warszawa 2012.

Oniszczuk J., Zainteresowania racjonalnością. Przykłady starszych podejść do racjonalności (kilka uwag), [w:] R.M. Czarny, K. Spryszak (red.), Państwo i prawo wobec wspótczesnych wyzwań. Teoria i filozofia państwa i prawa oraz aksjologia demokracji i ochrony praw człowieka. Księga jubileuszowa Profesora Jerzego Jaskierni, Toruń 2012.

Peno M., Nowoczesna polityka kryminalna w świetle koncepcji polityki tworzenia prawa Jerzego Wróblewskiego, [w:] T. Bekrycht, M. Zirk-Sadowski (red.), Wptyw teorii Jerzego Wróblewskiego na współczesne prawoznawstwo, Warszawa 2011. 
Peno M., Postmodernizacja nauki prawa karnego - geneza i efekty, [w:] A. Samonek (red.), Teoria prawa. Między nowoczesnościa a ponowoczesnościa, Kraków 2012.

Pietrzykowski T., Wyzwania moralne. Etyczne problemy prawa, Warszawa 2010.

Sarkowicz R., Poziomowa interpretacja tekstu prawnego, Kraków 1995.

Sulikowski A., O możliwościach postmodernizacji nauki prawa konstytucyjnego, „Państwo i Prawo" 2010, nr 12.

Sulikowski A., Współczesny paradygmat sądownictwa konstytucyjnego wobec kryzysu nowoczesności, Wrocław 2008.

Utrat-Milecki J., Prawo karne i polityka kryminalna jako podsystem kontroli społecznej. Analiza integralnokulturowa, [w:] M. Filar, J. Utrat-Milecki (red.), Kulturowe uwarunkowania polityki kryminalnej, Warszawa 2014.

Warylewski J., [w:] A. Marek (red.), System prawa karnego, t. I, Zagadnienia ogólne, Warszawa 2010.

Winczorek P., Konstytucja i wartości, [w:] J. Trzciński (red.), Charakter i struktura norm konstytucji, Warszawa 1997.

Wojciechowski B., Dekonstrukcja. Między prawem i sprawiedliwościa, [w:] L. Leszczyński (red.), Zmiany społeczne a zmiany w prawie, Lublin 1998.

Wojtyczek K., Polska nauka prawa konstytucyjnego na przełomie wieków, [w:] M. Zubik (red.), Dwadzieścia lat transformacji ustrojowej w Polsce, Warszawa 2010.

\section{SELECTED PROBLEMS OF THE PARADIGM OF JURISPRUDENCE}

\section{S u m m a r y}

The author draws attention to the postmodern critique of basic assumptions of the paradigm of jurisprudence, i.e., classical logic and ethics, rationalism and utilitarianism of the Enlightenment, and also positivism and naturalism. In particular, the author points out the contemporary neglect of profound research in the field of axiology of law, especially criminal law. He also emphasizes that the hermeneutics of the language of law semantically must be associated with a certain culture and its value system. The interpretation of law should pay attention to the meta-narrative context of the law, including original and relevant anthropological, ethical, social and cultural background of legislative decisions.

Key words: interpretation of the law, axiology of law, philosophy of law, legal science paradigm, postmodernism.

\section{ЗАМЕЧАНИЯ В ПРЕДМЕТЕ ПАРАДИГМЫ ЮРИДИЧЕСКИХ НАУК}

$$
\text { P е } 3 \text { го м е }
$$


Автор статьи обращает внимание, как нелегко вести нормативные исследования, которые возникают из сильного вдияния на уровне общей методологии наук постмодерной контестации оснований классической логики и этики, посвященному рационализму и утилитаризму, а также аксиому позитивизма, признанных доныне основными составдяющими парадигмы юридических наук. Автор в частности указывает на неблагосклонное окружение для ведения исследований, что касается аксиологии права в отдельных законодательных догмах, в частности в науке угодовного права. При этом подчеркивает, что герменевтика нормативных актов должна быть привязана семантически в культуре, которая создала систему правосудия и соответствующей ей системе ценностей. В объяснении права следует обратить особенное внимание, что кроется за юридическим языком, так называемый, аксиологический мета-рассказ, а именно, конкретный антропологический, этичный, общественный и культурный контекст, представляющий первичное, релевантное для содержания юридических норм фон аксиологичных и нормативных решений законодателя.

Ключевые слова: правое объяснение, правовая аксиология, правовая философия, парадигма юридических наук, постмодернизм.

Tłum. na j. rosyjski Michał Mościcki 